Article

\title{
Team Dynamics, Leadership, and Employee Proactivity of Vietnamese Firms
}

\author{
Tan Huynh ${ }^{1}$, Minh Hon Duong ${ }^{1}$, Thuy Thanh Phan ${ }^{1}$, Tu Van Do ${ }^{2}$, Truc Thi Thanh Do ${ }^{3}$ \\ and Khai The Nguyen ${ }^{4}$ * \\ 1 Faculty of Business Administration, Nguyen Tat Thanh University, Ho Chi Minh 700000, Vietnam; \\ htan@ntt.edu.vn (T.H.); dhminh@ntt.edu.vn (M.H.D.); pthanhthuy@ntt.edu.vn (T.T.P.) \\ 2 Faculty of Business Administration, University of Phan Thiet, Ho Chi Minh 700000, Vietnam; \\ dovantu@upt.edu.vn \\ 3 Faculty of Business Administration, Saigon Technology University, Ho Chi Minh 700000, Vietnam; \\ truc.dothithanh@stu.edu.vn \\ 4 Faculty of Business Administration, Ho Chi Minh City Open University, Ho Chi Minh 700000, Vietnam \\ * Correspondence: khai.nt@ou.edu.vn; Tel.: +84-94-3793939
}

Received: 28 January 2019; Accepted: 3 March 2019; Published: 8 March 2019

\begin{abstract}
Integrating the relational approach and social exchange theory, the authors conceptualize the quality of leader-member and team member exchanges as mediators for understanding the role of transformational leadership in employee proactive behaviors (e.g., voice, taking charge, and innovative behaviors). The results based on data collected from 352 full-time employees working in pharmaceutical companies in Vietnam largely support the proposed theoretical framework and shed light on the mechanism through which leadership style influences employee proactivity in a manufacturing context. Using the results, the authors discuss research limitation and, managerial implications, and suggest future research directions for the relationship between leadership style and employee proactive behavior.
\end{abstract}

Keywords: transformational leadership; leader-member exchange; team member exchange; proactive behavior; pharmaceutical companies

\section{Introduction}

In today's fast and competitive world, organizations expect their employees to be more proactive to adapt to a complex and uncertain work environment because proactive behaviors are beneficial to both individual-level (job and career attainment) [1-3] and organizational-level outcomes (organizational performance) [4-6]. A common topic in research on organizational citizenship behavior is the question of why employees engage in these important proactive behaviors [7]. However, most research has focused on the role of individual dispositional characteristics and immediate work environment features [8-11], while the role of broader contextual influences is mostly unexplored. There are still factors like situational opportunities and constraints at the organizational level that play a vital role in influencing essential employee behaviors, such as organizational citizenship behavior, absenteeism, turnover, and performance [12]. In addition, complex environments that are a result of increased collaborations between different players have in many ways necessitated a shift from closed to open systems that facilitate informal behavior to match situational and contextual factors [13].

There have been studies of the positive influence of transformational leadership (TL) on employee competence and attitudes $[14,15]$ because transformational leaders encourage followers with motivational interaction [16]. However, being proactive is also suitable for leader member exchange (LMX) and team member exchange (TMX) since higher-quality LMX relationships lead to 
larger perceptual convergence for employees with their managers on crucial characteristics of the organizational environment, and team members become an indispensable factor in deciding team performance [17]. Based on social learning theory, this study aims to investigate the mechanism of TL impact on proactive behavior (PB) through the meditating effects of LMX and TMX.

In recent years, $\mathrm{PB}$ has drawn the attention of researchers on organizational citizenship behavior (OCB). Moreover, research on PB in organizations shows a preference for the Western cultural context. Most of the studies were performed in Western countries, thus reflecting Western culture $[18,19]$. Staff competence may be related to leadership and management models $[20,21]$. Therefore, this is a valuable opportunity to conduct a study in a different context and culture. According to Vibiz.Vn's report [22], Vietnam's pharmaceutical industry has grown significantly, ranking 13th in the world for the fastest growth rate. In 2017, Vietnam's pharmaceutical market revenue reached about USD 5.2 billion, a 10.6\% increase from 2016. In recent years, many foreign investors, large international corporations, and even domestic companies operating outside the industry participated in the pharmaceutical sector. With strong growth momentum and a dynamic working environment that requires cooperation and strict compliance with complicated regulations, managers need to have a high level of leadership capacity in order to motivate all employees.

Indeed, transformational leadership needs to be considered in Vietnamese pharmaceutical companies because they lack high-quality human resources to operate manufacturing and business. One of the reasons is that employees are unhappy about the working environment as well as the leadership style of their superiors in management and operations. With the aim of finding the cause and remedy, we have created research models to analyze the determinants of transformational leadership on the quality of leader-member exchange, team member exchange, and the proactive behavior of employees at Vietnamese pharmaceutical companies.

Following recent research $[14,23,24]$, the purpose of this study is to provide a different perspective on the relationships between TL, LMX, TMX, and PB. The research hypotheses are based on the argument that LMX and TMX act as mediators, providing the necessary resources for employees to display PB.

\section{Theoretical Background and Hypothesis Development}

\subsection{Transformational Leadership}

Transformational leadership theory has become a subject of intense study in management research $[25,26]$. The concept of transformational leadership with regard to leader-member influence is strongly supported by researchers, namely Bass [27] and Yukl [28]. According to Bass [27], a transformational leader always treats members with a foundation of moral values and makes them feel appreciated, believed, admired, and loyal, and therefore they will have the encouragement to overcome mediocrity and bring about amazing results.

The influence of a leader on an employee is determined by two factors: first, idealized influence behavior, and second, idealized influence - an attribute that is indicated through interactions with members. Idealized influence behavior refers to actions that can create trust in bottom-line staff such as attention to ethics when making decisions, emphasis on the goals and mission of the group, transmission of values, and belief in the work [29]. As for the idealized influence attribute, it shows a member's personal feelings about the exemplary qualities that the leader reveals when interacting with members; some of the typical qualities are: self-confidence, personal power, and the nobility of the leader when willing to ignore self-interest for the benefit of the whole group [29].

Individualized consideration represents the listening and understanding of the leader with regard to the personal needs of the member. From this insight, the leader will be able to provide direct counseling or guidance to help members maximize their potential and thereby create a good base for them to satisfy the highest level of Maslow's hierarchy of needs: self-actualization [30]. 
Intellectual stimulation shows that leadership encourages members to be innovative in their work. Positive support from the leader is expressed through different groups of behaviors such as accepting conflicting opinions from members, not criticizing members when they make mistakes in the process of creating or applying new initiatives, and motivating members to ask questions about the values and beliefs that exist in their minds and in the daily operations of the organization. It is through these behaviors that employees will work harder to put forward many approaches that offer innovative ideas for solving organizational problems [28].

Inspirational motivation refers to leadership behaviors that motivate and encourage members to work by providing a compelling, persuasive, and empowering vision [31].

\subsection{Leader-Member Exchange}

Research related to the relationship between supervisors and subordinates, especially leader-member exchange (LMX), will shape team members' behavior. These studies address how members respond to their leaders or organizations to meet the interests of their leaders [32]. If members feel that they receive fair treatment, they are more likely to work harder by engaging in OCB. The origins of OCB can be traced back to the typical Western society in which subordinates have more freedom in shaping their roles and contexts. In the West, most researchers assume that subordinates have the resources and authority to respond by joining OCB whenever they wish to do so. Previous research has indicated that subordinates are willing to pay their debt by joining OCB without any limitation in their job roles. Members can repay leaders not only because they have the motivation but also because they have the ability and resources to work.

\subsection{Team-Member Exchange}

Seers [33] describe team member exchange (TMX) as the effect of work relationships among a team member and colleagues. It is an individual perception of the exchange relationship with the peer group as a whole. High TMX means that team members have great social and mission relationships and work to benefit their peers. This differs from LMX in that the relationship involves the whole peer group and the way people view themselves as members. Liu et al. [34] report that TMX indicates task interactions in team members and enhances performance, efficiency, and PB.

\subsection{Proactive Work Behavior of Employees}

Taking charge (TC) behavior is one employee behavior in the workplace and can be viewed as a contribution to organizational goals or to supervision [35]. TC occurs when members go beyond their basic duties and show real effort towards solving problems [36]. TC motivates members to actively explore issues. Compared with interest, the responsibility is more constructive because it can mitigate the consequences and prevent the repetition of recurring problems [36]. Moon et al. [37] described it as an often-overlooked aspect of innovative work behavior and also of willpower. This behavior can be improved and beneficial to the organization rather than being derived from personal gain [38].

Voice Behavior (VO): Graham and Van Dyne [39] defined voice behavior as behavior that raised the opinions of ethical and influential employees. This was predicted by the importance of the employee's experience to their work group, their level of self-esteem, and their belief in fairness. Voice behavior is defined as defined as expressing work-related ideas and opinions based on cooperative motive. [40]. Voice behavior expresses ideas when employees contribute constructive ideas to improve processes or work environments [10].

Innovative Work (IN) behavior is becoming increasingly important as the economic environment changes and the pace of globalization and the demand for competition increase rapidly; thus, there is growing interest in this field [41-43]. Innovative work behavior in the workplace can be defined as proactivity, promotion, and implementation of new ideas in a group or organization that is working for greater efficiency [44]. For example, finding new technology, proposing new ways to achieve goals, applying new working methods, investing, and securing resources for the implementation of new 
ideas [45]. The role of innovative work behavior is being emphasized by customer service-oriented organizations, which constantly expect and encourage employees to have innovative work behavior that improves service quality and increases efficiency [41,42,46-49].

\subsection{Research Hypotheses}

Transformational leadership encourages employee self-confidence by specifying their expectations, giving feedback, providing helpful advice for development, urging employees to have new approaches to complete work, and complimenting the skills and performance of employees [50]. Such behaviors make members realize the consideration and support of TL and this strengthens their emotional relationship. TL also transfers to members by extending compliments to the whole team for its achievement and inspiring collective visions or goals through the image of a group's future [15]. In addition, many studies show that TL has a positive impact on PB [51-53] based mainly on the following arguments. First, transformational leaders are an example to follow because they tend to actively improve their work through creativity, future orientation, and taking responsibility for their decisions $[52,54]$. Second, TL encourages and empowers employees to find creative solutions, so employees might be more likely to speak up by making constructive suggestions $[55,56]$. Finally, TL enhances a positive influence through regular emotional connections between employees and the organization's vision [52,57].

Thus, the hypotheses propose:

H1a: Transformational leadership has a positive relationship with taking charge of employees.

H1b: Transformational leadership has a positive relationship with the voice behavior of employees.

H1c: Transformational leadership has a positive relationship with the innovative work behavior of employees.

Transformational leadership will develop a follower's relational identity by interpersonal interaction [14], such as communicating high expectations, follower development, intellectual stimulation, and personal recognition. The behaviors of caring and support from a transformational leader enable followers to identify such leaders and reciprocate through hard work, trust, and respect $[58,59]$. Consequently, high-quality relationships between leaders and followers emerge. The empirical research of Wang et al. [60]; Ilies et al. [59], and Martin et al. [61] also supports this argument. Thus, we hypothesize:

\section{H2a: Transformational leadership has a positive relationship with LMX.}

When transformational leadership clarifies and emphasizes group identity, team vision, and team building, individualists will follow collectivism and replace "I" with "we" [62]. Therefore, the members accept the mission and task of the group. Members have the same interests and values; they help each other in the work, provide constructive feedback and advice, and respect other colleagues [63]. TMX quality also improves the sense of loyalty, identification, and belonging to the whole $[34,64]$. The social exchange chains in the group represent the general exchange characteristics, which is one of the important characteristics of TMX. Moreover, transformational leaders often encourage autonomy so that members of the group increase their connections, think outside the box, and face greater challenges [65]. Thus, the proposed theory is that transformational leadership can help members build a collective identity and help employees develop team member exchange.

H2b: Transformational leadership has a positive relationship with TMX.

Social exchange theory emphasizes interdependence in human society, hoping individuals support those who have helped them before and repay the good they receive [66]. Social relationships in organizations influence the enthusiasm of the members in their work [67]. Social penetration theory also suggests that the depth of the relationship affects the level of disclosure between individuals. Self-disclosure can be in the form of speech (ideas), nonverbal (emotional signals), and behavioral expressions (actions). The high quality of relationships with leaders and coworkers is 
often accompanied by strong emotional attachment [64], and members are encouraged to express their opinions because they feel valued [68]. In contrast, when the relationship is less intimate the sharing of ideas may be limited. Expressing opinions in this situation becomes more difficult because employees perceive their ability to be poorly perceived [69]. In short, the higher the leader-member exchange and team member exchange, the more motivated the employee is to express proactive behavior.

H3: Leader-member exchange has a positive relationship with employees' proactive behavior (TC, VO, IN).

Previous studies have shown that energy and vitality are two important components of innovation [70]. When a person is in a positive relationship, he or she is more likely to contribute in the workplace, especially in complex tasks or in the pursuit of innovation [24]. Team member exchange can enhance the level of individual autonomy, namely better control of job performance [71] and a sense of empowerment [72]. Studies by Ohly et al. [73] and Zhang and Bartol [74] show that relationships among team members are as good as motivating employees to engage in innovative work. Thus, the hypothesis is proposed as follows:

H4: Team member exchange quality has a same-direction relationship with employees' proactive behavior.

\subsection{Suggested Research Model}

From the theoretical basis, prior studies, and the actual situation of the companies, the suggested research model is as Figure 1 follows:

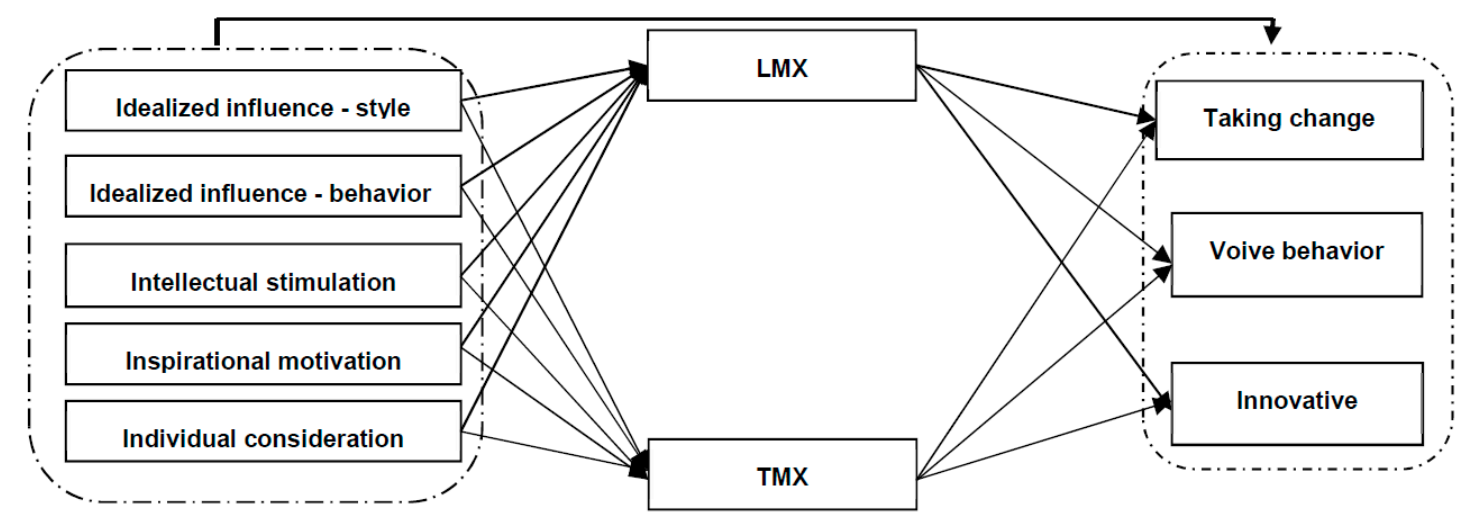

Figure 1. Research model.

\section{Methodology}

\subsection{Approach and Research Method}

Research is organized into two steps: preliminary and official. Preliminary research is conducted through in-depth interviews with 10 employees at many levels in pharmaceutical companies. The official research is conducted by quantitative methods, assembling data through direct interviews and questionnaires in e-mails to employees of pharmaceutical companies. The collected information is processed and translated into statistical results with the help of SPSS and AMOS software.

\subsection{Choosing the Sample}

Samples in the official research were chosen using a convenient sampling method. Questionnaires were sent directly via e-mail to employees working in different positions in full-time work at pharmaceutical companies in Vietnam. The research was supported by the human resources departments of pharmaceutical companies in sending survey forms to voluntary employees participating in the survey. The information is only to be used for research purposes and we showed a commitment to information security for respondents. 


\subsection{Research Scale}

The research scale is based on previous studies on TL, LMX, and PB. The TL measurement contains four dimensions (21 items) as per Bass and Avolio [75]: idealized influence (eight items), intellectual stimulation (four items), individualized consideration (four items), and inspirational motivation (four items). These were rated using a five-point Likert scale ranging from 1 (strongly disagree) to 5 (strongly agree).

LMX was measured using the 6-item scale of Liden and Maslyn [76]. This construct was measured using a 5-point, Likert-type scale ranging from 1 (strongly disagree) to 5 (strongly agree).

TMX was measured using the instrument developed by Seers [77]. TMX construct was measured using a 5-point, Likert-type scale ranging from 1 (strongly disagree) to 5 (strongly agree).

The VO measurement comprises six items and was developed by Van Dyne and LePine [56]. The IN measurement is based on the Scott and Bruce [78] scale for individual innovative behavior in the workplace. The TC measure was developed by Morrison and Phelps [36]. The scale is incorporated in the questionnaire and respondents provide self-reports. The response is measured on a 5-point scale ranging from 1 (never) to 5 (always).

\section{Results}

\subsection{Sample Statistics}

Among 352 valid questionnaires (from 365 questionnaires), the sample was categorized in groups for convenience. Domestic pharmaceutical companies accounted for $41.64 \%$, foreign-invested companies accounted for $18.08 \%$, and foreign-invested companies accounted for $40.27 \%$. Male gender accounted for $56.71 \%$ and female was $43.29 \%$. In terms of age, the group under 30 years old accounted for $21.10 \%$, the age group 30 to 40 years accounted for $55.07 \%$, and the group over 40 years old surveyed accounted for $23.84 \%$. In terms of seniority, subjects with under five years of work experience at the company accounted for $28.77 \%$, from five to 10 years accounted for $55.07 \%$, subjects, and subjects with over 10 years' experience accounted for $16.16 \%$. In terms of income, the group with an income of less than VND 10 million accounts for $27.12 \%$, the income from VND 10 to 20 million accounts for $47.95 \%$, and the group earning over VND 20 million accounts for $24.93 \%$. Statistical results show that employees in the pharmaceutical company are mainly young, dynamic employees. The most common working period is from five to 10 years, and the income is mostly from 10 to 20 million VND per month.

\subsection{Scale Evaluation}

Table 1 shows means, standard deviations, Cronbach's $\alpha$, and correlations of the latent constructs in the measurement model. All of the correlations were smaller than 0.85 , suggesting the absence of multi-collinearity [79]. All factors have a Cronbach's $\alpha$ larger than 0.7; if skipping any observable variables in these factors, the alpha number will decrease. Meanwhile, the "Corrected Item-Total Correlation" in the scale are greater than 0.3, so all observations are kept. Evaluating the correlation between variables by a Pearson test gave the results in Table 1: most independent variables correlate with the dependent variable at the $99 \%$ confidence level, with correlation coefficients $\geq 0.3$. correlations between variables. 
Table 1. Mean (M), Cronbach's $\alpha$ testing result, standard deviations (SD), and intercorrelations of study variables.

\begin{tabular}{|c|c|c|c|c|c|c|c|c|c|c|c|c|c|c|}
\hline Variable & & $\mathbf{M}$ & $\begin{array}{c}\text { Cronbach's } \\
\alpha\end{array}$ & SD & 1 & 2 & 3 & 4 & 5 & 6 & 7 & 8 & 9 & 10 \\
\hline $\begin{array}{l}\text { 1. Idealized } \\
\text { influence-style }\end{array}$ & PC & 3.52 & 0.827 & 0.63 & 1 & & & & & & & & & \\
\hline $\begin{array}{l}\text { 2. Idealized } \\
\text { influence-behavior }\end{array}$ & $\mathrm{HV}$ & 3.63 & 0.826 & 0.70 & $\begin{array}{c}0.36 \\
* *\end{array}$ & 1 & & & & & & & & \\
\hline $\begin{array}{l}\text { 3. Inspirational } \\
\text { motivation }\end{array}$ & $\mathrm{CH}$ & 3.44 & 0.906 & 0.73 & $\begin{array}{c}0.29 \\
* *\end{array}$ & $\begin{array}{c}0.64 \\
* *\end{array}$ & 1 & & & & & & & \\
\hline $\begin{array}{l}\text { 4. Intellectual } \\
\text { stimulation }\end{array}$ & TT & 3.49 & 0.774 & 0.65 & $\begin{array}{c}0.39 \\
* *\end{array}$ & $\underset{* *}{0.32}$ & $\underset{* *}{0.31}$ & 1 & & & & & & \\
\hline $\begin{array}{l}\text { 5. Individual } \\
\text { consideration }\end{array}$ & QT & 3.94 & 0.789 & 0.56 & $\underset{* *}{0.26}$ & $\begin{array}{c}0.23 \\
* *\end{array}$ & $\underset{*}{0.10}$ & $\begin{array}{c}0.51 \\
* *\end{array}$ & 1 & & & & & \\
\hline 6. LMX & LMX & 3.67 & 0.758 & 0.79 & $\begin{array}{c}0.32 \\
*\end{array}$ & $\underset{* *}{0.30}$ & 0.27 & $\begin{array}{c}0.61 \\
* *\end{array}$ & $\begin{array}{c}0.51 \\
* *\end{array}$ & 1 & & & & \\
\hline 7. TMX & TMX & 3.99 & 0.928 & 0.61 & $\begin{array}{c}0.35 \\
* *\end{array}$ & $\begin{array}{c}0.32 \\
* *\end{array}$ & $\begin{array}{c}0.23 \\
* *\end{array}$ & $\begin{array}{c}0.38 \\
* *\end{array}$ & $\begin{array}{c}0.29 \\
* *\end{array}$ & $\begin{array}{c}0.31 \\
* *\end{array}$ & 1 & & & \\
\hline 8. Voice behavior & $\mathrm{VO}$ & 3.19 & 0.862 & 0.70 & $\begin{array}{c}0.25 \\
* *\end{array}$ & $\begin{array}{c}0.31 \\
* *\end{array}$ & $\begin{array}{c}0.21 \\
* *\end{array}$ & $\begin{array}{c}0.13 \\
*\end{array}$ & $\begin{array}{c}0.32 \\
* *\end{array}$ & $\begin{array}{c}0.37 \\
*\end{array}$ & $\begin{array}{c}0.35 \\
* *\end{array}$ & 1 & & \\
\hline 9. Taking charge & $\mathrm{TC}$ & 3.51 & 0.843 & 0.63 & $\begin{array}{c}0.09 \\
* *\end{array}$ & $\begin{array}{c}0.42 \\
* *\end{array}$ & $\begin{array}{c}0.35 \\
* *\end{array}$ & $\begin{array}{c}0.24 \\
* *\end{array}$ & $\begin{array}{c}0.27 \\
*\end{array}$ & $\begin{array}{c}0.35 \\
* *\end{array}$ & $\underset{* *}{0.24}$ & $\begin{array}{c}0.45 \\
* *\end{array}$ & 1 & \\
\hline $\begin{array}{l}\text { 10. Innovative } \\
\text { work behavior }\end{array}$ & IN & 3.48 & 0.854 & 0.58 & $\begin{array}{c}0.31 \\
* *\end{array}$ & $\begin{array}{c}0.25 \\
* *\end{array}$ & 0.28 & $\begin{array}{c}0.55 \\
* *\end{array}$ & $\begin{array}{c}0.48 \\
* *\end{array}$ & 0.32 & $\begin{array}{c}0.13 \\
* *\end{array}$ & $\begin{array}{c}0.39 \\
* *\end{array}$ & $\begin{array}{c}0.56 \\
*\end{array}$ & 1 \\
\hline
\end{tabular}

\subsection{Analysis of CFA Decisive Factor}

In this study, we performed a confirmatory factor analysis (CFA) through structural equation modeling (SEM) in AMOS 20. The CFA results show that the model has indicators revealing the suitability of the model with market information. Based on the Chi-square/df $=2.356(<3)$, RMSEA $=0.062(<0.08), \mathrm{GFI}=0.826, \mathrm{TLI}=0.891, \mathrm{CFI}=0.903>0.9)$ are standard [79]. This result indicates that the measurement model fits well with the data. Table 2 shows that the standardized weights of the scale are both high, higher than 0.5 , and the $p$-value of each pair is lower than 0.05 . Moreover, the correlation coefficients together with the standard deviations show that they are different from 1 . Thus, the adjusted research model achieves convergence value and discriminating value. The model has no correlation among the measurement errors of the factor groups, so the model becomes monad.

Table 2. Convergent and discriminant validity coefficients.

\begin{tabular}{lcccccccccccc}
\hline Constructs & $\begin{array}{c}\text { AVE } \\
(>\mathbf{0 . 5})\end{array}$ & $\begin{array}{c}\text { CR } \\
(>\mathbf{0 . 7})\end{array}$ & $\mathbf{1}$ & $\mathbf{2}$ & $\mathbf{3}$ & $\mathbf{4}$ & $\mathbf{5}$ & $\mathbf{6}$ & $\mathbf{7}$ & $\mathbf{8}$ & $\mathbf{9}$ & $\mathbf{1 0}$ \\
\hline 1. PC & 0.92 & 0.99 & $\mathbf{0 . 9 6}$ & & & & & & & & \\
\hline 2. HV & 0.74 & 0.94 & 0.22 & $\mathbf{0 . 8 6}$ & & & & & & & \\
\hline 3. CH & 0.94 & 0.98 & 0.14 & 0.25 & $\mathbf{0 . 9 7}$ & & & & & & & \\
\hline 4. TT & 0.83 & 0.93 & 0.17 & 0.18 & 0.19 & $\mathbf{0 . 9 1}$ & & & & & & \\
\hline 5. QT & 0.93 & 0.99 & 0.24 & 0.22 & 0.13 & 0.22 & $\mathbf{0 . 9 6}$ & & & & & \\
\hline 6. LMX & 0.90 & 0.96 & 0.27 & 0.19 & 0.25 & 0.39 & 0.21 & $\mathbf{0 . 9 5}$ & & & \\
\hline 7. TMX & 0.95 & 0.99 & 0.16 & 0.15 & 0.26 & 0.42 & 0.07 & 0.01 & $\mathbf{0 . 9 7}$ & & \\
\hline 8. VO & 0.85 & 0.92 & 0.22 & 0.11 & 0.13 & 0.18 & 0.05 & 0.06 & 0.22 & $\mathbf{0 . 9 2}$ & & \\
\hline 9. TC & 0.76 & 0.84 & 0.11 & 0.24 & 0.17 & 0.23 & 0.13 & 0.36 & 0.05 & 0.18 & $\mathbf{0 . 8 7}$ & \\
\hline 10. IN & 0.89 & 0.91 & 0.14 & 0.22 & 0.18 & 0.15 & 0.08 & 0.26 & 0.04 & 0.32 & 0.26 & $\mathbf{0 . 9 4}$ \\
\hline
\end{tabular}




\subsection{SEM Suitability Assessment.}

The theoretical model was tested with the MLE technique. Figure 2 shows the final structural model with acceptable goodness-of-fit, along with indicators and their standardized factor loadings, standardized path coefficients, and error terms for endogenous constructs. Consider the $p$-value: if $p$-value $\leq 0.05$, the hypothesis of the relationship of these two concepts is supported. In contrast, if $p$-value $>0.05$, the hypothesis is rejected. The standardized regression coefficient shows the degree of influence of these concepts on the other.

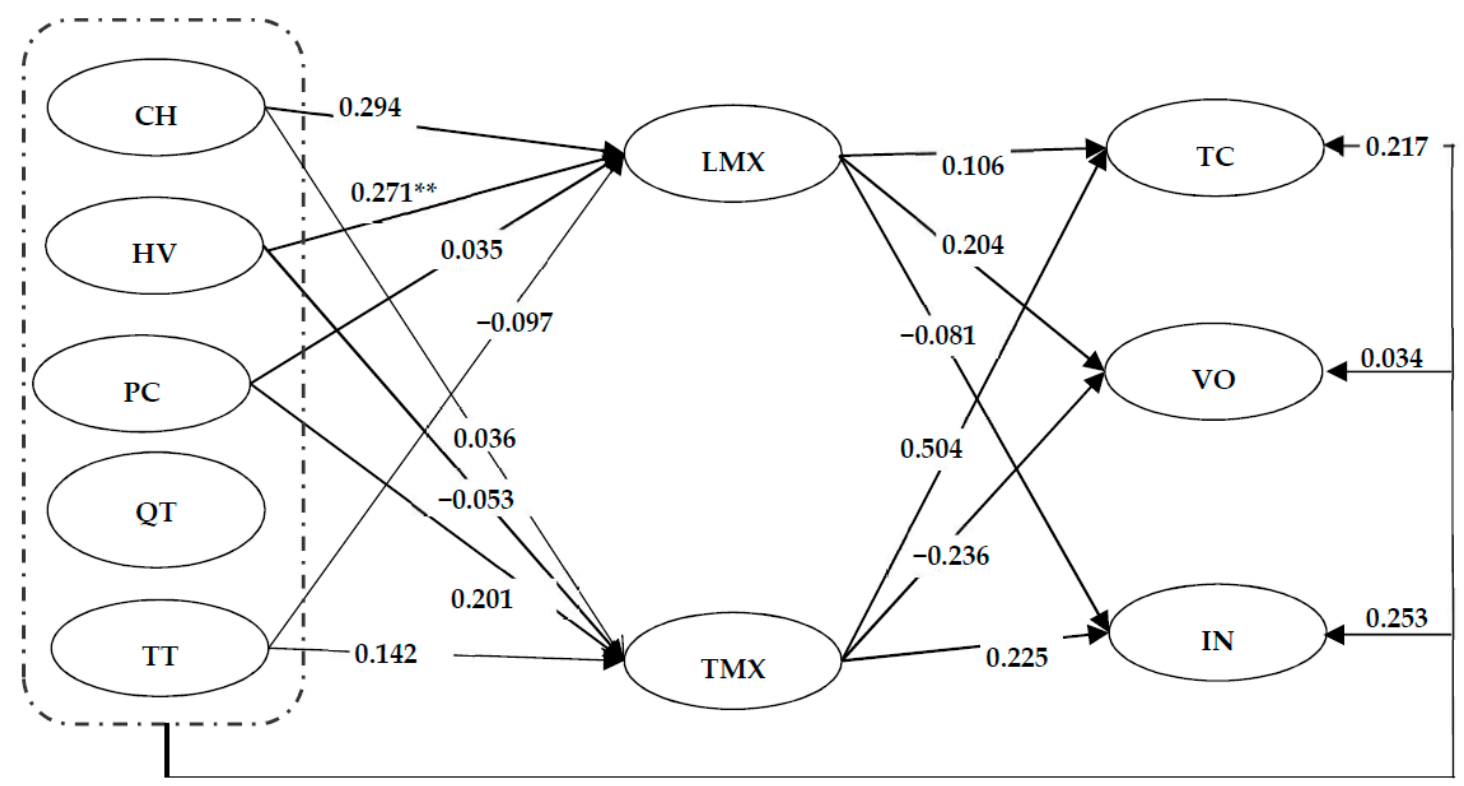

Figure 2. The structural model.

Estimated results of the model with Chi-square are $1522.532(p=0.000)$. Other criteria are as follows: $\mathrm{GFI}=0.840$; $\mathrm{TLI}=0.847, \mathrm{CFI}=858$ and RMSEA $=0.068$. In order to broaden the overall research results, the model should be tested for reliability. The subject used the bootstrapping technique with a repeated sample size of 1.500 observations $(n=1.500)$. Estimates of 1.500 observations indicate that the original weights are significant for the average weight of bootstrapping since all weights are within the $95 \%$ reliable interval. Thus, the estimates in the model can be concluded to be reliable.

Details of hypothesis testing results are shown in the table as follows (Table 3):

Table 3. Results of the verification of causal relationships between the model concepts.

\begin{tabular}{ccccccccc}
\hline Hypothesis & & Content & & Estimate & S.E. & C.R. & P & Testing \\
\hline H1a & TC & $<-$ & TL & 0.217 & 0.035 & 3.543 & 0.008 & Accepted \\
\hline H1b & VO & $<-$ & TL & 0.034 & 0.027 & 5.023 & $* * *$ & Accepted \\
\hline H1c & IN & $<-$ & TL & 0.253 & 0.052 & 2.316 & $* * *$ & Accepted \\
\hline H2a1 & LMX & $<-$ & CH & 0.294 & 0.061 & 4.831 & $* * *$ & Accepted \\
\hline H2a2 & LMX & $<-$ & HV & 0.271 & 0.065 & 4.146 & $* * *$ & Accepted \\
\hline H2a3 & LMX & $<-$ & PC & 0.035 & 0.117 & 0.299 & 0.765 & $\begin{array}{c}\text { Not } \\
\text { accepted }\end{array}$ \\
\hline
\end{tabular}


Table 3. Cont.

\begin{tabular}{ccccccccc}
\hline Hypothesis & & Content & & Estimate & S.E. & C.R. & P & Testing \\
\hline H2a4 & LMX & $<-$ & TT & 0.097 & 0.103 & 0.938 & 0.348 & $\begin{array}{c}\text { Not } \\
\text { accepted }\end{array}$ \\
\hline H2a5 & LMX & $<-$ & QT & 0.17 & 0.064 & 2.673 & 0.008 & Accepted \\
\hline H2b1 & TMX & $<-$ & CH & 0.36 & 0.053 & 6.823 & $* * *$ & Accepted \\
\hline H2b2 & TMX & $<-$ & HV & 0.24 & 0.054 & 4.409 & $* * *$ & Accepted \\
\hline H2b3 & TMX & $<-$ & PC & -0.053 & 0.098 & -0.543 & 0.587 & $\begin{array}{c}\text { Not } \\
\text { accepted }\end{array}$ \\
\hline H2b4 & TMX & $<-$ & TT & 0.142 & 0.086 & 1.651 & 0.099 & Accepted \\
\hline H1b5 & TMX & $<-$ & QT & 0.201 & 0.054 & 3.735 & $* * *$ & Accepted \\
\hline H3a & TC & $<-$ & LMX & 0.106 & 0.054 & 1.962 & 0.05 & Accepted \\
\hline H3b & IN & $<-$ & LMX & -0.081 & 0.059 & -1.378 & 0.168 & $\begin{array}{c}\text { Not } \\
\text { accepted }\end{array}$ \\
\hline H3c & VO & $<-$ & LMX & 0.204 & 0.064 & 3.19 & 0.001 & Accepted \\
\hline H4a & TC & $<-$ & TMX & 0.504 & 0.066 & 7.681 & $* * *$ & Accepted \\
\hline H4b & IN & $<-$ & TMX & 0.225 & 0.067 & 3.365 & $* * *$ & Accepted \\
\hline H4c & VO & $<-$ & TMX & -0.236 & 0.071 & -3.319 & $* * *$ & Accepted \\
\hline Note: ${ }^{*}$ Significant level at $p<0.001, * *$ Significant level at $p<0.005$. Source: Calculations of authors.
\end{tabular}

As shown in Table 3, the hypotheses with $p$-value ranging from 0.000 to 0.023 (all with $p$-value < 0.05 ) are accepted. However, four hypotheses, H2a3, H2a4, H2b3, and H3b, were not accepted.

The present study answers a recent call by researchers to provide a more distinguish picture of the relationship between transformational leadership and employees' proactive work behavior [80]. Our study addressed the role of LMX and TMX as an affective-motivational state in this relationship to enhance PB. The results show a positive relationship between TL and PB. This is in line with previous research suggesting that TL relates positively to $\mathrm{PB}[80,81]$.

Overall, the research results are consistent with other recent studies $[23,82]$. Our research contributes to existing documents on proactiveness by explaining the impact of TL on TC, VO, and IN through the support of LMX and TMX.

In quantitative methods of sampling, it is common practice to divide the sample into two sub-samples. Half is used to estimate model parameters and half is used for re-evaluation. Another way is to repeat the study with another sample. The two methods are often unrealistic because linear structural analysis usually requires large sample sizes, which costs a lot of time and money [83]. In such cases, bootstrap is the right approach. This study uses a bootstrap method with a repeated sample size of one thousand five hundred to test the reliability of the theoretical model estimates. Estimates of one thousand five hundred observations indicate that the original weights are significant for the average weight of bootstrapping since all weights are within the $95 \%$ confidence interval. Thus, the estimates in the model can be concluded to be reliable.

The results of path analysis with SEM show that the hypothesized model is consistent with the data. The results of the standardized coefficients of the proposed relationships among constructs in the model are statistically significant $(p<0.05)$. As a result, transformational leadership has a positive impact on TMX components such as inspirational motivation, idealized influence behavior, and intellectual stimulation, and consideration. Factors influencing styles are not statistically significant. TMX has a strong impact on employees' voice behavior and innovative work behavior. 


\subsection{Discussion: Open Innovation as Employee Proactivity and the Role of Open Innovation as the Trigger of Employee Proactivity}

In the developing world in the 21st century, PB is considered an important factor that focuses on increasing productivity, adaptability, and capacity. This is accomplished by changing attitudes, behaviors, values, strategies, processes, and organizational structures that can adapt to competitive activities, advanced technology, and the speed of change in the environment. Our findings create deeper insight into the drivers of PB among employees by focusing on empowered employees and their relationships with their leader and team. TL promotes an employee's creativity as well as his/her ability to persuade others to apply novel ideas. TL provides employees with autonomy and freedom by emphasizing the meaning and worth of work roles. They encourage the intellectual abilities of employees and inspire them to create opportunities to significantly affect their work roles, which prompts more elevated levels of $\mathrm{PB}$.

Research in the area of proactive work behavior is relatively new, but studies have shown how TL affects LMX, TMX, and PB. In accordance with Chan et al. (2014), the research results show that TL plays an important role in innovation behavior. In addition, consistent with Wang et al.'s [84] and Jaiswal et al.'s research [85], these results reveal that TL has a positive correlation with PB. Based on previous studies and related empirical research, we extended the use of SET to explain the way that a leader can impact on employees' behavior. In this study, we demonstrated how a good quality of TMX representing intimate relationships among members can promote PB in a group [86-88]. Our finding that problem-solving behaviors are related to TL also provides deeper insight into the reciprocal impacts in the leader-member relationship (LMX) and especially confirms the idea that followers can influence their leaders in the leadership process [89]. Our finding is that TL is the main factor that encourages followers to build collective identity; meanwhile, this identity makes followers develop high-quality relationships with colleagues. This is similar to the research of Mortara and Minshall [90] about the importance of creating an open-innovation culture to succeed. To implement open innovation, it is useful to form a team that focuses on open innovation culture. They should help and encourage employees within the company by creating networks and bringing external resources into research and development. An open innovation team is also vital to creating and maintaining lasting relationships with institutions and other partners. They should help overcome resistance to open innovation by supporting managers as well as supplying tools for new functions.

The theoretical contribution of this study is to the existing research of the constructs in the aspect of advancing previous research by empirically examining the relations between them. The theoretical and practical contribution is in the presented results that mediate the role of LMX and TMX in the relationship between TL and PB, similar to the research of Zou et al. [91]. However, Zou et al. [91] conducted their study within the single industry of hotel in the context of Chinese culture. As far as we are aware, our study is one of the first to test the link between TL, LMX, TMX, and PB, thereby extending the literature in this area.

The speed of innovation is remarkably important in this era since lead time and product life cycle are short and customers require value. Innovation is a way for business players with limited resources to profit through proactively finding industrial knowledge and engaging with stakeholders (suppliers, users) from around the world [92]. In our study, innovation is most successful when managers involved in innovation have ties with major external partners and in the existence of suitable organizational structure. These are some insights that could help encourage open innovation.

However, some hypotheses are not acceptable (Table 3), which is different from the findings of previous studies mostly carried out in Western contexts. This may be caused by individual and cultural differences, as employees in the Asian context are more collectivistic and prefer achieving goals set by the organization to pursuing personal goals that hinder innovative solutions.

Cultural differences may be a reasonable explanation for the differences between this study and previous ones. Research by Jung et al. [93] in Taiwan and Gumusluoglu and Ilsev [94] in Turkey also reveal that the relationship between TL and IWB is not supported. Based on a study on national 
culture by Hofstede [95], research proposes two main reasons for this difference: power distance and individualism/collectivism in Western culture and Eastern culture.

Power distance is the degree to which less powerful members of institutions and organizations accept that power is distributed unequally. In Eastern culture power often rests with senior leaders, so employees do not have the right of self-determination. In Western low-power culture, leaders and employees are more equal, and cooperate more to achieve organizational goals. In the low power distance culture, employees do not wait for the manager's permission to do the job. While in the higher power distance culture, on the contrary, employees expect the permission of the leader and the support of the working group.

Second, the individual versus collective nature of Eastern and Western cultures is very different. In Eastern countries like Vietnam, the relationship between individuals plays a more important role than personal will. Business is conducted on the basis of teamwork, in which collective opinions are always valued; solidarity and sympathy help individuals to be confident in the PB.

\section{Conclusions}

\subsection{Conclusions}

The results of the model analysis have found the same relationship between transformational leadership style and TMX, and the positive impact of TMX on the voice behavior and innovation of employees. Analyzing the level of proactive work behavior shows that the assessment of the components is not high; most of the assessments have not yet reached level 4 . This shows that enterprises need to improve the quality of the relationship between the members and promote the proactive work behavior of the employees. Moreover, firms ought to make more effort to create training programs that enhance their managers' TFL style. In addition, they should employ and promote people who are extroverted and emotionally stable since these individuals have great potential to become transformational leaders [15].

\subsection{Managerial Implications}

Following the analysis of the impact of transformational leadership on proactive work behavior, our research gives several suggestions about how the leader's behavior can improve members' performance, as shown below. These are basic recommendations based on the parts of the TL. First, managers can become impactful models and use verbal persuasion to motivate employees to be innovative [15]. Second, to encourage creative thinking, TL can create hands-on chances for subordinates to apply new skills to tackle intricate problems [96]. Third, transformational leaders can provide personal support and individualized development guidance to help ease potential feelings of anxiety or dread that might appear in employees due to the inherent uncertainties of innovative attempts [97]. These behaviors may facilitate innovation behavior by creating an organizational climate that supports PB. Furthermore, our findings reveal that TMX positively affects PB, so encouraging exchange and mutual understanding among team members is essential. Organizations should also have regular training programs for both leaders and employees to improve LMX and TMX. Organizations with TL managers and a suitable organizational environment will encourage employees to devote their efforts to the organization through PB.

\subsection{Limitations and Future Research}

The current study employed a quantitative approach; future researchers could collect qualitative data to gain deeper insight into findings in related fields. In addition, this study investigated pharmaceutical companies' employees, a very specific target sample, which limits the generalizability of the findings to other groups or populations. Hence, future studies should target the employees of other industries or examine interdepartmental teams of different organizations through methods such as investigating PB. 
This research was only carried out in the pharmaceutical field in Vietnam. Further research should expand to other industries or countries to learn more about the impact of other factors on proactive work behavior.

Author Contributions: Investigation, M.H.D., T.V.D. and T.T.T.D.; Methodology, T.T.P.; Supervision, K.T.N.; Writing —original draft, T.H.

Funding: This research received no external funding.

Acknowledgments: The authors thank the anonymous reviewers for their insightful comments and constructive suggestions. We also thank the board of directors and company staff for supporting us in conducting the research.

Conflicts of Interest: The authors declare no conflict of interest.

\section{References}

1. Fuller, B., Jr.; Marler, L.E. Change driven by nature: A meta-analytic review of the proactive personality literature. J. Vocat. Behav. 2009, 75, 329-345. [CrossRef]

2. Ng, T.W.H.; Eby, L.T.; Sorensen, K.L.; Feldman, D.C. Predictors of Objective and Subjective Career Success: A Meta-Analysis. Pers. Psychol. 2005, 58, 367-408. [CrossRef]

3. Tornau, K.; Frese, M. Construct clean-up in proactivity research: A meta-analysis on the nomological net of work-related proactivityconcepts and their incremental validities. Appl. Psychol. 2012, 62, 44-96. [CrossRef]

4. Frese, M.; Fay, D. Personal Initiative (PI): An Active Performance Concept for Work in the 21st Century. Res. Organ. Behav. 2001, 23, 133-187. [CrossRef]

5. Griffin, M.A.; Neal, A.; Parker, S.K. A New Model of Work Role Performance: Positive Behavior in Uncertain and Interdependent Contexts. Acad. Manag. J. 2007, 50, 327-347. [CrossRef]

6. Spitzmuller, M.; Van Dyne, L. Proactive and reactive helping: Contrasting the positive consequences of different forms of helping. J. Organ. Behav. 2013, 34, 560-580. [CrossRef]

7. Dierdorff, E.C.; Norton, J.J.; Gregory, C.M.; Rivkin, D.; Lewis, P. ONET's national perspective on the greening of the world of work. In Green Organizations: Driving Change with IO Psychology; Huffman, A.H., Klein, S.R., Eds.; Routledge: New York, NY, USA, 2012; pp. 348-378. [CrossRef]

8. Fritz, C.; Sonnentag, S. Antecedents of day-level proactive behavior: A look at job stressors and positive affect during the workday. J. Manag. 2009, 35, 94-111. [CrossRef]

9. Lam, C.F.; Spreitzer, G.; Fritz, C. Too much of a good thing: Curvilinear effect of positive affect on proactive behaviors. J. Organ. Behav. 2014, 35, 530-546. [CrossRef]

10. Parker, S.K.; Collins, C.G. Taking stock: Integrating and differentiating multiple proactive behaviors. J. Manag. 2010. [CrossRef]

11. Parker, S.K.; Williams, H.; Turner, N. Modeling the antecedents of proactive behavior at work. J. Appl. Psychol. 2006, 91, 636-652. [CrossRef]

12. Johns, G. The Essential Impact of Context on Organizational Behavior. Acad. Manag. Rev. 2006, 31, 386-408. [CrossRef]

13. Brodbeck, P.W. Complexity theory and organization procedure design. Bus. Process Manag. J. 2002, 8, 377-402. [CrossRef]

14. Walumbwa, F.O.; Hartnell, C.A. Understanding transformational leadership-employee performance links: The role of relationsl identification and self-efficacy. J. Occup. Organ. Psychol. 2011, 84, 53-172. [CrossRef]

15. Wang, G.; Oh, I.-S.; Courtright, S.H.; Colbert, A.E. Transformational leadership and performance across criteria and levels: A meta-analytic review of 25 years of research. Group Organ. Manag. 2011, 36, 223-270. [CrossRef]

16. Bono, J.E.; Ilies, R. Charisma, Positive Emotions and Mood Contagion. The Leadership Quarterly. 2006, 17, 317-334. [CrossRef]

17. Herdman, A.O.; Yang, J.; Arthur, J.B. How Does Leader-Member Exchange Disparity Affect Teamwork Behavior and Effectiveness in Work Groups: The Moderating Role of Leader-Leader. Exch. J. Manag. 2014, 43, 1498-1523. [CrossRef]

18. Umar, M.; Hassan, Z. Antecedents and Outcomes of Voice and Silence Behaviours of Employees of Tertiary Educational Institutions in Nigeria. Procedia Soc. Behav. Sci. 2013, 97, 188-193. [CrossRef] 
19. Brinsfield, C.T.; Edwards, M.; Greenberg, J. Voice and silence in organizations: Historical review and current conceptualizations. In Voice and Silence in Organizations; Greenberg, J., Edwards, M., Eds.; Emerald Group Publishing: Bingley, UK, 2009.

20. Sung, S.Y.; Choi, J.N. Do organizations spend wisely on employees? Effects of training and development investments on learning and innovation in organizations. J. Organ. Behav. 2014, 35, 393-412. [CrossRef]

21. Thompson, J. Transformational leadership can improve workforce competencies. Nurs. Manag. UK 2012, 18, 21-24. [CrossRef]

22. Vibiz Report. Available online: http://vibiz.vn/bao-cao-gan-day/-vibiz-report-nganh-duoc-pham-hientrang-2017-va-xu-huong-phat-trien-2022.html (accessed on 1 October 2018).

23. Strauss, K.; Parker, S. Intervening to Enhance Proactivity in Organizations: Improving the Present or Changing the Future. J. Manag. 2015, 44, 1250-1278. [CrossRef]

24. Vinarski-Peretz, H.; Binyamin, G.; Carmeli, A. Subjective relational experiences and employee innovative behaviors in the workplace. J. Vocat. Behav. 2011, 78, 290-304. [CrossRef]

25. Mhatre, K.H.; Riggio, R.E.; Handbooks, O. Charismatic and Transformational Leadership: Past, Present, and Future. In The Oxford Handbook of Leadership and Organizations; Oxford University Press: Oxford, UK, 2014; pp. 221-224.

26. Banks, G.C.; Mc Cauley, K.D.; Gardner, W.L.; Guler, C.E. A meta-analytic review of authentic and transformational leadership: A test for redundancy. Leadersh. Q. 2016, 27, 634-652. [CrossRef]

27. Bass, B.M. Leadership and Performance beyond Expectations; Free Press: New York, NY, USA, 1985.

28. Yukl, G. Leadership in Organizations, 7th ed.; Pearson: Upper Saddle River, NJ, USA, 2010.

29. Antonakis, J.; Avolio, B.J.; Sivasubramaniam, N. Context and leadership: An examination of nine-factor full-range leadership theory using the Multifactor Leadership Questionnaire. Leadersh. Q. 2003, 14, 261-295. [CrossRef]

30. Northouse, P.G. Leadership: Theory and Practice, 5th ed.; Sage: Thousands Oaks, CA, USA, 2010.

31. Bass, B.M.; Jung, D.I.; Avolio, B.J.; Berson, Y. Predicting unit performance by assessing transformational and transactional leadership. J. Appl. Psychol. 2003, 88, 207-218. [CrossRef] [PubMed]

32. Podsakoff, P.M.; Mackenzie, S.B.; Paine, J.B.; Bachrach, D.G. Organizational Citizenship Behaviors: A Critical Review of the Theoretical and Empirical Literature and Suggestions for Future Research. J. Manag. 2000, 26, 513-563. [CrossRef]

33. Seers, A.; Petty, M.M.; Cashman, J.F. Team-member exchange under team and traditional management: A naturally occurring quasiexperiment. Group Organ. Manag. 1995, 20, 18-38. [CrossRef]

34. Liu, Y.; Keller, R.T.; Shih, H.-A. The impact of team-member exchange, differentiation, team commitment, and knowledge sharing on R\&D project team performance. $R$ D Manag. 2011, 41, 274-287. [CrossRef]

35. Hodson, R. The active worker. Compliance and autonomy at the workplace. J. Contemp. Ethnogr. 1991, 20, 47-78. [CrossRef]

36. Morrison, E.W.; Phelps, C.C. Taking charge at work: Extra-roleefforts to initiate workplace change. Acad. Manag. J. 1999, 42, 403-419. [CrossRef]

37. Moon, H.; Van Dyne, L.; Wrobel, K. The circumplex model and the future of organizational citizenship research. In A Handbook on Organizational Citizenship Behavior: A Review of "Good Soldier" Activity in Organizations; Turnipseed, D., Ed.; Nova Science: New York, NY, USA, 2005; pp. 3-23.

38. Moon, H.; Kamdar, D.; Mayer, D.M.; Takeuchi, R. Me or we? The role of personality and justice as other-centered antecedents to innovative citizenship behaviors within organizations. J. Appl. Psychol. 2008, 93, 84-94. [CrossRef] [PubMed]

39. Graham, J.W.; Van Dyne, L. Gathering information and exercising influence: Two forms of civic virtue organizational citizenship behavior. Empl. Responsib. Rights J. 2006, 18, 89-109. [CrossRef]

40. Liu, W.; Zhu, R.; Yang, Y. I warn you because I like you: Voice behavior, employee identifications, and transformational leadership. Leadersh. Q. 2010, 21, 189-202. [CrossRef]

41. Chen, W.-J. Innovation in hotel services: Culture and personality. Int. J. Hosp. Manag. 2011, 30, 64-72. [CrossRef]

42. Kim, T.T.; Lee, G. Hospitality employee knowledge-sharing behaviors in the relationship between goal orientations and service innovative behavior. Int. J. Hosp. Manag. 2013, 34, 324-337. [CrossRef]

43. Akram, T.; Lei, S.; Haider, M.J. The impact of relational leadership on employee innovative work behavior in IT industry of China. Arab Econ. Bus. J. 2016, 11, 153-161. [CrossRef] 
44. Janssen, O. How fairness perceptions make innovative behavior more or less stressful. J. Organ. Behav. 2004, 25, 201-215. [CrossRef]

45. Yuan, F.; Woodman, R.W. Innovative behavior in the workplace: The role of performance and image outcomes expectations. Acad. Manag. J. 2010, 53, 323-342. [CrossRef]

46. Luoh, H.-F.; Tsaur, S.-H.; Tang, Y.-Y. Empowering employees: Job standardization and innovative behavior. Int. J. Contemp. Hosp. Manag. 2014, 26, 1100-1117. [CrossRef]

47. Dhar, R.L. The effects of high performance human resource practices on service innovative behavior. Int. J. Hosp. Manag. 2015, 51, 67-75. [CrossRef]

48. Li, M.; Hsu, C.H. A review of employee innovative behavior in services. Int. J. Contemp. Hosp. Manag. 2016, 28, 2820-2841. [CrossRef]

49. Afsar, B.; Badir, Y. Workplace spirituality, perceived organizational support and innovative work behavior. J. Workplace Learn. 2017, 29, 95-109. [CrossRef]

50. Belias, D.; Koustelios, A. Leadership and Job Satisfaction-are view. Eur. Sci. J. 2014, 10, 24-46. [CrossRef]

51. Belschak, F.D.; Den Hartog, D.N. Pro-self, prosocial, and pro-organizational foci of proactive behaviour: Differential antecedents and consequences. J. Occup. Organ. Psychol. 2010, 83, 475-498. [CrossRef]

52. Den Hartog, D.N.; Belschak, F.D. When does transformational leadership enhance employee proactive behavior? The role of autonomy and role breadth self-efficacy. J. Appl. Psychol. 2012, 97, 194-202. [CrossRef] [PubMed]

53. Schmitt, A.; Den Hartog, D.N.; Belschak, F.D. Transformational leadership and proactive work behaviour: A moderated mediation model including work engagement and job strain. J. Occup. Organ. Psychol. 2016, 89, 588-610. [CrossRef]

54. Crant, J.M.; Bateman, T.S. Charismatic leadership viewed from above: The impact of proactive personality. J. Organ. Behav. 2000, 14, 63-75. [CrossRef]

55. Morrison, E.W. Employee voice behavior: Integration and directions for future research. Acad. Manag. Ann. 2011, 5, 373-412. [CrossRef]

56. Van Dyne, L.; LePine, J.A. Helping and voice extra-role behaviors: Evidence of construct and predictive validity. Acad. Manag. J. 1998, 41, 108-119. [CrossRef]

57. Bindl, U.K.; Parker, S.K.; Totterdell, P.; Hagger-Johnson, G. Fuel of the self-starter: How mood relates to proactive goal regulation. J. Appl. Psychol. 2012, 97, 134-150. [CrossRef]

58. Graen, G.B.; Uhl-Bien, M. Relationship-based approach to leadership: Development of leader-member exchange (LMX) theory of leadership over 25 years: Applying a multi-level multi-domain perspective. Leadersh. Q. 1995, 6, 219-247. [CrossRef]

59. Ilies, R.; Nahrgang, J.D.; Morgeson, F.P. Leader-member exchange and citizenship behaviors: A meta-analysis. J. Appl. Psychol. 2007, 92, 269-277. [CrossRef]

60. Wang, H.; Law, K.S.; Hackett, R.D.; Wang, D.X.; Chen, Z.X. Leader-member exchange as a mediator of the Relationship between transformational leadership and follower's Performance and Organizational citizenship Behavior. Acad. Manag. J. 2005, 48, 420-432. [CrossRef]

61. Martin, R.; Guillaume, Y.; Thomas, G.; Lee, A.; Epitropaki, O. Leader-member exchange (LMX) and performance: A meta-analytic review. Pers. Psychol. 2016, 69, 67-121. [CrossRef]

62. Bryman, A.; Gillingwater, D.; Mc Guinness, I. Leadership and Organisational Transformation. Manag. Res. News 1992, 26-27. [CrossRef]

63. Kark, R.; Shamir, B. The Influence of Transformational Leadership on Followers' Relational versus Collective Self-Concept. Acad. Manag. Annu. Meet. Proc. 2002, D1-D6. [CrossRef]

64. Liao, H.; Liu, D.; Loi, R. Looking at both sides of the social exchange coin: A social cognitive perspective on the joint effects of relationship quality and differentiation on creativity. Acad. Manag. J. 2010, 53, 1090-1109. [CrossRef]

65. Tse, H.H.M.; Dasborough, M.T. A study of exchange and emotions in team member relationships. Group Organ. Manag. 2008, 33, 194-215. [CrossRef]

66. Gouldner, A. The norm of reciprocity: A preliminary statement. American Sociological Review. 1960, 25, 161-178. [CrossRef]

67. Albrecht, S.L. The influence of job, team and organizational level resources on employee well-being, engagement, commitment and extra-role performance. Int. J. Manpow. 2012, 33, 840-853. [CrossRef] 
68. Morrison, E.W.; Milliken, F.J. Speaking up, remaining silent: The dinamics of voice and silent in organizations. J. Manag. Stud. 2003, 40, 1353-1358. [CrossRef]

69. Lepper, M.R.; Greene, D.; Nisbett, R.E. Undermining children's intrinsic interest with extrinsic reward: A test of the 'overjustification' hypothesis. J. Personal. Soc. Psychol. 1973, 28, 129-137. [CrossRef]

70. Atwater, L.; Carmeli, A. Leader-member exchange, feelings of energy, and involvement in creative work. Leadersh. Q. 2009, 20, 264-275. [CrossRef]

71. Unsworth, K.L.; Clegg, C.W. Why do employees undertake creative action? J. Occup. Organ. Psychol. 2010, 83,77-99. [CrossRef]

72. Liden, R.C.; Erdogan, B.; Wayne, S.J.; Sparrowe, R.T. Leader-member exchange, differentiation, and task interdependence: Implications for individual and group performance. J. Organ. Behav. 2006, 27, 723-746. [CrossRef]

73. Ohly, S.; Sonnentag, S.; Pluntke, F. Routinization, work characteristics and their relationships with creative and proactive behaviors. J. Organ. Behav. 2006, 27, 257-279. [CrossRef]

74. Zhang, X.; Bartol, K.M. Linking empowering leadership and employee creativity: The influence of psychological empowerment, intrinsic motivation, and creative process engagement. Acad. Manag. J. 2010, 53, 107-128. [CrossRef]

75. Bass, B.M.; Avolio, B.J. Multifactor Leadership Questionnaire Manual and Sampler Set, 3rd ed.; Mindgarden: Redwood City, CA, USA, 2004. [CrossRef]

76. Liden, R.C.; Maslyn, J.M. Multidimensionality of leader-member exchange: An empirical assessment through scale development. J. Manag. 1998, 24, 43-72. [CrossRef]

77. Seers, A. Team-member exchange quality: A new construct for role-making research. Organ. Behav. Hum. Decis. Process. 1989, 43, 118-135. [CrossRef]

78. Scott, S.G.; Bruce, R.A. Determinants of Innovative Behavior: A Path Model of Individual Innovation in the Workplace. Acad. Manag. J. 1994, 37, 580-607.

79. Hair, J.F.; Black, W.; Babin, B.J.; Anderson, R.E. Multivariate Data Analysis; Prentice Hall: Upper Saddle River, NJ, USA, 2010.

80. Den Hartog, D.N.; Belschak, F.D. Personal initiative, commitment and affect at work. J. Occup. Organ. Psychol. 2007, 80, 601-622. [CrossRef]

81. Straus, S.E.; Tetroe, J.; Graham, I. Defining knowledge translation. CMAJ 2009, 181, 165-168. [CrossRef] [PubMed]

82. Parker, S.; Mason, C.; Griffin, M. Transformational leadership development: Connecting psychological and behavioral change. Leadersh. Organ. Dev. J. 2014, 35, 174-194. [CrossRef]

83. Anderson, J.; Gerbing, D.W. Structural Equation Modeling in Practice: A Review and Recommended Two-Step Approach. Psychol. Bull. 1988, 103, 411-423. [CrossRef]

84. Wang, P.; Rode, J.C.; Shi, K.; Luo, Z.; Chen, W. A workgroup climate perspective on the relationships among transformational leadership, workgroup diversity, and employee creativity. Group Organ. Manag. 2013, 38, 334-360. [CrossRef]

85. Jaiswal, N.K.; Dhar, R.L. Transformational leadership, innovation climate, creative self-efficacy and employee creativity: A multilevel study. Int. J. Hosp. Manag. 2015, 51, 30-41. [CrossRef]

86. Cole, M.; Schaninger, W.; Harris, S. The workplace social network exchange: A multilevel, conceptual examination. Group Organ. Manag. 2007, 27, 142-167. [CrossRef]

87. Cropanzano, R.; Mitchell, M.S. Social exchange theory: An interdisciplinary review. J. Manag. 2005, 31, 874-900. [CrossRef]

88. Maurer, T.J.; Pierce, H.R.; Shore, L.M. Perceived beneficiary of employee development activity: A three-dimensional social exchange model. Acad. Manag. Rev. 2002, 27, 432-444. [CrossRef]

89. Dvir, T.; Shamir, B. Follower developmental characteristics as predicting transformational leadership: A longitudinal field study. Leadersh. Q. 2003, 14, 327-344. [CrossRef]

90. Mortara, L.; Minshall, T. Creating an environment for Open Innovation. In IFM Briefing; Institute for Manufacturing, University of Cambridge: Cambridge, UK, 2009; Volume 1.

91. Zou, W.-C.; Zheng, Y.; Liu, J. The impact of transformational leadership on the helping behavior of hotel employee. J. Econ. Bus. Manag. 2015, 3, 322-325. [CrossRef]

92. Chesbrough, H. Bringing Open Innovation to Services. MIT Sloan Manag. Rev. 2011, 52, 85-90. 
93. Jung, D.I.; Chow, C.; Wu, A. The role of transformational leadership in enhancing organizational innovation: Hypotheses and some preliminary findings. Leadersh. Q. 2003, 14, 525-544. [CrossRef]

94. Gumusluoglu, L.; Ilsev, A. Transformational Leadership, Creativity, and Organizational Innovation. J. Bus. Res. 2009, 62, 461-473. [CrossRef]

95. Hofstede, G. Dimensionalizing Cultures: The Hofstede Model in Context. Online Read. Psychol. Cult. $2011,2$. [CrossRef]

96. Sarros, J.C.; Cooper, B.K.; Santora, J.C. Building a climate for innovation through transformational leadership and organizational culture. J. Leadersh. Organ. Stud. 2008, 15, 145-158. [CrossRef]

97. Chen, G.; Farh, J.-L.; Campbell-Bush, E.M.; Wu, Z.; Wu, X. Teams as innovative systems: Multilevel motivational antecedents of innovation in R\&D teams. J. Appl. Psychol. 2013, 98, 1018-1027.

(C) 2019 by the authors. Licensee MDPI, Basel, Switzerland. This article is an open access article distributed under the terms and conditions of the Creative Commons Attribution (CC BY) license (http:/ / creativecommons.org/licenses/by/4.0/). 